\title{
Perlindungan Pekerja Rumah Tangga Dalam Sistem Hukum Nasional
}

\author{
Sonhaji \\ Fakultas Hukum, Universitas Diponegoro \\ Jl. Prof. Soedarto, SH Tembalang Semarang \\ E-mail : sonhajimuh19@gmail.com
}

\begin{abstract}
The role of house worker is very important in our daily life. Developing of work frame fo house worker are more extend and complex as advance as the era. Kencana foundation is foundation which dealing the house assistant, in this case is house worker, for giving further information of implementation, obstacles and efforts, the rights of house worker they have ever had. From this research, there are some conclutions, that implementation of ministral regulation No:2/2015 about protection of house worker can't be applied well, and we still finding obstacles and short comings. The obstacles are the violance, experienced by house worker, salary wihch accordances with the aggrement, and any other neglect of the rights of house worker. Given that most of the house worker come from low basic education so they don't even know/realize about their rights and duties exactly from that ministral regulation. Because of that, socialization must be done continously to quaranty the protection of law for the house worker.
\end{abstract}

Key words: protection of law , house worker

\begin{abstract}
Abstrak
Peran Pekerja Rumah Tangga dalam kehidupan sehari-hari amat penting. Perkembangan ruang lingkungan pekerjaan, bagi buruh yang bekerja dirumah atau Pekerja Rumah Tangga sesuai dengan kemajuan zaman, ternyata semakin luas dan kompleks. Yayasan Kencana merupakan Yayasan Penyalur Pekerja Rumah Tangga yang menyalurkan tenaga kerja dalam hal ini adalah Pekerja Rumah Tangga, Untuk mengetahui sejauh mana pelaksanaan, hambatan-hambatan dan upaya-upaya yang dilakukan untuk memenuhi hak-hak Pekerja Rumah Tangga yang seharusnya mereka dapat, penulis mengambil judul "Pelaksanaan Perlindungan Bagi Pekerja Rumah Tangga Berdasarkan Peraturan Menteri Nomor 2 Tahun 2015 Tentang Perlindungan Pekerja Rumah Tangga".Dari hasil penelitian ini dapat disimpulkan bahwa Pelaksanaan Peraturan Menteri Nomor 2 Tahun 2015 tentang Perlindungan Pekerja Rumah Tangga belum dapat diterapkan dengan baik, dan masih ditemui adanya kekurangan dan hambatan. Hambatan-hambatan tersebut antara lain terdapatnya kekerasan yang dialami pekerja rumah tangga, adanya upah yang tidak sesuai dengan yang diperjanjikan, dan adanya pengabaian hakhak pekerja rumah tangga yang lainnya. Mengingat Pekerja Rumah Tangga kebanyakan datang dari pendidikan rendah sehingga kurang memahami hak maupun kewajibannya yang tercantum dalam peraturan menteri tersebut. Oleh karena itu perlu dilakukan sosialisasi yang terus menerus untuk menjamin perlindungan hukum bagi Pekerja Rumah Tangga.
\end{abstract}

Kata Kunci : Perlindungan Hukum, Pekerja Rumah Tangga 


\section{A. Pendahuluan}

Peran pekerja rumah tangga dalam kehidupan sehari-hari amat penting. Perkembangan ruang lingkungan pekerjaan, bagi buruh, yang bekerja dirumah, atau PRT sesuai dengan kemajuan zaman, ternyata semakin luas dan kompleks.Dalam melaksanakan pekerjaannya, seorang pekerja rumah tangga dituntut untuk menguasai banyak ketrampilan untuk mendukung pekerjaannya. Dari mulai memasak, mencuci, merawat kebun, keahlian mengandarai kendaraan bermotor untuk keperluan antarjemput anak, merawat anak, dan orangtua, bahkan mendampingi anak majikan ketika waktunya belajar. Penggunaan pekerja rumah tangga dilatar belakangi oleh beberapa alasan, diantaranya adalah kesibukan majikan pada kegiatan sehari-hari, rasa malas oleh pasangan suami istri untuk merawat dan membersihkan rumah, kurangnya kemampuan memasak pada istri, terbatasnya waktu majikan untuk mengasuh anak. Dan masih banyak lagi alasan-alasan yang lain. Faktor-faktor tersebutlah yang membuat penggunanaan pekerja rumah tangga menjadi tinggi.

Dilihat dari peranan pekerja rumah tangga di dalam sebuah rumah sangat penting, maka sudah selayaknya para pekerja rumah tangga mendapatkan perlindungan hukum untuk menjamin hak-haknya saat mereka bekerja. Perlindungan hukum tersebut antara lain meliputi 1 hak-hak dasar pekerja antara lain menyangkut : perlindungan upah, jam kerja, tunjangan hari raya, jaminan sosial tenaga kerja, kompensasi PHK, dan hak istirahat/cuti. Seperti yang kita tahu, penggunaan jasa pekerja rumah tangga tidak menggunakan perjanjian kerja, karena pada dasarnya majikan mendapatkan pekerja rumah tangga melalui sebuah lembaga penyalur pekerja rumah tangga sesuai dengan wilayah pengguna pekerja rumah tangga itu sendiri. Sehingga hal tersebut membuat majikan dan pekerja rumah tangga tidak menggunakan perjanjian kerja terlebih dahulu saat majikan mempekerjakan pekerja rumah tangga. Padahal perjanjian kerja sangatlah penting bagi seseorang yang memulai kerja, karena disitulah akan mengetahui bagaimana hak dan kewajiban kedua belah pihak akan diatur. ${ }^{1}$

Dengan melihat latar belakang tersebut permasalahan yang akan dibahas dalam penulisan hukum ini adalah : Bagaimana pelaksanaan perlindungan terhadap Pembantu

1Editus Libertus. Hak-hak pekerja wanita. (Jakarta : Visimedia,2008), halaman 87 
Administrative Law \& Governance Journal. Volume 3 Issue 2, June $2020 \mid$ ISSN. 2621-2781 Online

Rumah Tangga berdasarkan Peraturan Menteri Ketenagakerjaan Nomor 2 Tahun 2015 tentang Perlindungan Pekerja Rumah Tangga ? Hambatan-hambatan apa saja yang ada dalam pelaksanaan Peraturan Menteri Ketenagakerjaan Nomor 2 Tahun 2015 ?

\section{B. Metode Penelitian}

Metode pendekatan dalam penelitian ini menggunakan metode pendekatan yuridis empiris yaitu pendekatan yang dilakukan dengan cara mengadakan penelitian secara langsung kelapangan, dengan melihat penerapan peraturan perundang-undangan atau aturan hukum lain yang berkaitan dengan masalah yang diteliti dan spesifikasi penelitian memakai penelitian deskriptif analitis yang masuk dalam kategori penelitian kasus atau studi kasus sehingga berpengaruh terhadap metode pengumpulan data yang akan digunakan.

Pekerja adalah setiap penduduk dalam usia kerja yang melakukan kegiatan ekonomis, baik dalam hubungan kerja di perusahaan maupun di luar hubungan kerja seperti pekerja mandiri, pekerja keluarga dan pekerja di sektor informal lainnya. 2 Undang-undang No. 13 Tahun 2003 tentang Ketenagakerjaan Pasal 1 Ayat (4) memberikan pengertian: "Pekerja/buruh adalah setiap orang yang bekerja dengan menerima upah atau imbalan dalam bentuk apapun."

Untuk kepentingan santunan jaminan kecelakaan kerja dalam perlindungan Jaminan Sosial Tenaga Kerja (Jamsostek) berdasarkan undang-undang No. 3 Tahun 1992, pengertian "pekerja" diperluas yakni termasuk : Magang dan murid yang bekerja pada perusahaan baik yang bekerja pada perusahaan baik yang menerima upah maupun tidak; Mereka yang memborong pekerjaan kecuali jika yang memborong adalah perusahaan; Narapidana yang dipekerjakan perusahaan.

Berdasarkan pengertian di atas dapat disimpulkan bahwa pekerja adalah setiap orang yang bekerja di perusahaan maupun di luar hubungan kerja dengan menerima upah atau imbalan dalam bentuk apapun. Imbalan tidak hanya berupa uang tetapi juga bisa berupa barang.

Terdapat syarat-syarat untuk menjadi seorang Pekerja Rumah Tangga, menurut Pasal 4 Peraturan Menteri Ketenagakerjaan nomor 2 tahun 2015 tentang Perlindungan

2 Payaman Simanjuntak. 2003. Manajemen Hubungan Industrial. Jakarta: Pustaka Sinar Harapan. Halaman 35 
Pekerja Rumah Tangga syarat-syarat untuk menjadi Pekerja Rumah Tangga adalah sebagai berikut : Persyaratan PRT meliputi : Memiliki dokumen identitas diri; Berusia minimal 18 (delapan belas) tahun; dan Mendapat izin dari suami/isteri bagi PRT yang sudah berkeluarga.

Pengaturan tentang Pekerja Rumah Tangga telah diatur dalam Peraturan Menteri Ketenagakerjaan nomor 2 tahun 2015 tentang Perlindungan Pekerja Rumah Tangga . Barnes menyatakan bahwa seorang pekerja tidak dapat diharapkan bekerja sehari penuh tanpa adanya gangguan. Selama bekerja seorang pekerja membutuhkan waktu berhenti sejenak untuk kebutuhan pribadinya, untuk istirahat dan untuk alasanalasan lain di luar kemapuannya. Oleh karenanya dalam menghitung waktu kerja efektif yang harus dijalani seorang pekerja setiap hari perlu diperhitungkan waktu istirahat atau kelonggaran (relaxation allowences) ${ }^{3}$

Hak-hak Pekerja Rumah Tangga diatur dalam Pasal 7 Peraturan Menteri Ketenagakerjaan nomor 2 tahun 2015. Hak-hak Pekerja Rumah Tangga adalah sebagai berikut: memperoleh informasi mengenai Pengguna; mendapat perlakuan yang baik dari Pengguna dan anggota keluarganya; mendapatkan upah sesuai Perjanjian Kerja; mendapatkan makanan dan minuman yang sehat; mendapatkan waktu istirahat yang cukup; mendapatkan hak cuti sesuai kesepakatan; mendapatkan kesempatan melakukan ibadah sesuai dengan agama dan kepercayaan yang dianutnya; mendapat tunjangan hari raya; dan berkomunikasi dengan keluarganya.

Kewajiban Pekerja Rumah Tangga diatur dalam Pasal 8 Peraturan Menteri Ketenagakerjaan nomor 2 tahun 2015 tentang Perlindungan Pekerja Rumah Tangga. Kewajiban Pekerja Rumah Tangga adalah sebagai berikut : melaksanakan tugas dan tanggungjawab sesuai dengan Perjanjian Kerja; menyelesaikan pekerjaan dengan baik; menjaga etika dan sopan santun di dalam keluarga Pengguna; memberitahukan kepada Pengguna dalam waktu yang cukup apabila PRT akan berhenti bekerja.

3 Barnes, R.M, 1980, Motions and Time Study Design and Measurement of Work, Seventh Edition, Prentice Hall International, Inc 
Administrative Law \& Governance Journal. Volume 3 Issue 2, June $2020 \mid$ ISSN. 2621-2781 Online

\section{Hasil dan Pembahasan}

1. Pelaksanaan Perlindungan Hukum Bagi Pekerja Rumah Tangga Pada Yayasan Kencana Semarang

Perjanjian Kerja merupakan unsur yang terpenting dalam melakukan hubungan kerja. Hal ini diatur dalam Pasal 1 Angka 14 Undang-Undang Nomor 3 Tahun 2013 tentang Ketenagakerjaan yang menyebutkan bahwa Perjanjian Kerja adalah perjanjian antara pekerja/buruh dengan pengusahan atau pemberi kerja yang memuat syarat-syarat kerja, hak, dan kewajiban para pihak. Hal tersebut sebanding dengan Pekerja Rumah Tangga yang ingin melakukan hubungan kerja dengan majikan, maka pada dasarnya harus mengadakan perjanjian kerja terlebih dahulu, seperti yang telah disebutkan dalam Peraturan Menteri Nomor 2 Tahun 2015 Pasal 5 yaitu : "Pengguna dan PRT wajib membuat Perjanjian Kerja tertulis atau lisan yang memuat hak dan kewajiban dan dapat dipahami oleh kedua belah pihak serta diketahui oleh Ketua Rukun Tetangga atau dengan sebutan lain".Perjanjian kerja yang dibuat baik perjajian kerja waktu tertentu(PKWT) atau perjanjian kerta waktu tidak tertentu (PKWTT) telah memberikan kepastian hukum bagi para pihak19. Dengan diadakannya Perjanjian Kerja maka terdapat hak dan kewajiban antara kedua belah pihak yang harus dipenuhi. Menurut Peraturan Menteri Nomor 2 Tahun 2015 Pasal 7 hak-hak PRT adalah sebagai berikut :

a. memperoleh informasi mengenai Pengguna;

b. mendapatkan perlakuan yang baik dari Pengguna dan anggota keluarganya;

c. mendapatkan upah sesuai Perjanjian Kerja;

d. mendapatkan makanan dan minuman yang sehat;

e. mendapatkan waktu istirahat yang cukup;

f. mendapatkan hak cuti sesuai kesepakatan;

g. mendapatkan kesempatan melakukan ibadah sesuai dengan agama dan kepercayaan yang dianutnya;

h. mendapatkan tunjangan hari raya; dan

i. berkomunikasi dengan keluarganya.

Sedangkan menurut Peraturan Menteri Nomor 2 Tahun 2015 Pasal 8 kewajiban yang harus dipenuhi PRT adalah sebagai berikut : 
1.melaksanakan tugas dan tanggungjawab sesuai dengan Perjanjian Kerja;

2.menyelesaikan pekerjaan dengan baik;

3.menjaga etika dan sopan santun di dalam keluarga pengguna; dan

4.memberitahukan kepada Pengguna dalam waktu yang cukup apabila PRT akan berhenti bekerja.

Namun dalam faktanya, Perjanjian Kerja yang seharusnya dilakukan oleh Pengguna dengan Pekerja Rumah Tangga tidak pernah terjadi. Sehingga hal ini menyebabkan tidak dapat terpenuhinya hak-hak Pekerja Rumah Tangga yang seharusnya diperoleh secara maksimal. Meskipun demikian, terdapat beberapa hakhak Pekerja Rumah Tangga yang telah terpenuhi, antara lain dalam pemenuhan hak mendapatkan tunjangan hari raya. Tunjangan hari raya adalah pendapatan pekerja yang wajib dibayarkan oleh kepada pekerja atau keluarganya menjelang Hari Raya Keagamaan yang berupa uang atau bentuk lain. Tunjangan hari raya ini hanya diberikan sekali dalam setahun yang selambat-lambatnya 7 hari menjelang hari raya keagamaan sesuai dengan agama masing-masing pekerja. Secara umum, jumlah THR yang berhak diterima oleh pekerja Pekerja Rumah Tangga yang sudah bekerja selama minimal setahun adalah mendapatkan sebulan gaji ${ }^{4}$.Disisi lain pemenuhan hak waktu istirahat yang cukup tidak dapat terlaksana dengan baik, karena pada dasarnya Pekerja Rumah Tangga penuh waktu yang berarti bahwa Pekerja Rumah Tangga tinggal bersama dalam satu rumah dengan pengguna jasa dalam hal ini adalah majikan. Pekerja Rumah Tangga yang demikian berarti harus siap 24 jam penuh untuk melayani majikan. Dengan demikian hal tersebut dapat dikatakan tidak manusiawi. Karena seorang pekerja rumah tangga juga membutuhkan istirahat yang cukup untuk memelihara kesehatannya. Pekerja Rumah Tangga memulai pekerjaannya pada pukul 05.00-21.00, kemudian pada pukul 21.00 pekerja seharusnya sudah beristirahat, namun jika diatas jam 21.00 majikan masih memerlukan pekerja untuk mengerjakan sesuatu maka pekerja harus siap untuk melaksanakan tugas yang diberikan majikan tersebut ${ }^{5}$.Hak untuk mendapatkan perlakuan yang baik dari Pengguna merupakan salah satu hak yang seharusnya diperoleh Pekerja Rumah Tangga, perlakuan yang

4 Suparmi,wawancara, PRT, Semarang, 14 Mei 2016

5 Yuslimah, wawancara, PRT, Semarang, 14 Mei 2016 
Administrative Law \& Governance Journal. Volume 3 Issue 2, June $2020 \mid$ ISSN. 2621-2781 Online

baik berarti bahwa memberikan perlakuan yang manusiawi kepada pekerja rumah tangga, perlakuan tersebut antara lain berupa tidak adanya tindak kekerasan yang dilakukan majikan terhadap pekerja rumah tangga.

\section{Hambatan-hambatan Dalam Pelaksanaan Perlindungan Hukum}

\section{Terhadap Pekerja Rumah Tangga di Yayasan Kencana}

Hambatan yang dialami Yayasan Kencana dalam memberikan perlindungan bagi Pekerja Rumah Tangga adalah : Perlakuan Kekerasan Dalam Rumah Tangga yang sering di alami oleh Pekerja Rumah Tangga.Perlakuan kekerasan yang dialami Pekerja Rumah Tangga dimana Pekerja Rumah Tangga tidak berani melaporkan adanya kekerasan tersebut. Hal ini dimungkinkan terjadi disebabkan oleh hal-hal sebagai berikut : Bahwa anggapan atau pemikiran masyarakat tentang bahaya dari kekerasan dalam rumah tangga, karena sebagian dari mereka menganggap bahwa masalah KDRT adalah masalah pribadi dalam keluarga sehingga tidak perlu untuk dibawa keluar rumah tangga ${ }^{6}$;

Dalam keluarga yang mempunyai ekonomi tinggi, lebih memilih hukuman denda dari pada hukuman penjara, hal ini menunjukkan bahwa dalam ekonomi menengah keatas cenderung menggap ringan masalah KDRT; Faktorfaktor yang menjadi penyebab kasus Pekerja Rumah Tangga sulit diselesaikan hingga tingkat pengadilan, antara lain meliputi : adanya upaya damai dengan penyelesaian masalah secara kekeluargaan dan adanya upaya damai dengan pemberian kompensasi berupa pemberian sejumlah uang oleh pelaku KDRT terhadap korban KDRT walaupun sebenarnya KDRT itu merupakan kejahatan dan dapat dipidana. Pemberian upah yang tidak sesuai dengan yang diperjanjikan semula. Pengabaian hak-hak Pekerja Rumah Tangga yang lainnya

\section{Upaya untuk Mengatasi HambatanDalam Pelaksanaan Perlindungan}

\section{Hukum Terhadap Pekerja Rumah Tangga di Yayasan Kencana}

Upaya untuk mengatasi hambatan yang dialami Yayasan Kencana dalam memberikan perlindungan bagi korban kekerasan dalam rumah tangga. Yayasan Kencana telah berupaya melakukan sosialisasi tentang Undang-

6 Mahmudah, wawancara, PRT,Semarang, tanggal 14 Mei 2016 
Undang Penghapusan Kekerasan Dalam Rumah Tangga terhadap Pekerja Rumah Tangga dan Pengguna. Bahwa Pekerja Rumah Tangga juga manusia biasa yang membutuhkan perlakuan baik sebagaimana mestinya mengingat pekerjaan yang telah Pekerja Rumah Tangga lakukan cukup berat dan sudah seharusnya Pekerja Rumah Tangga diperlakukan secara manusiawi juga mendapatkan perlindungan hukum.

Yayasan Kencana telah berusaha menyampaikan mengenai isi Perjanjian Kerja yang dilakukan antara kedua belah pihak dalam hal ini adalah Pekerja Rumah Tangga dengan Pengguna. Dimana dalam Perjanjian Kerja terdapat syarat-syarat, hak, dan kewajiban yang harus dipenuhi oleh masingmasing pihak. Terutama dalam hal pengupahan, bahwa pembayaran upah harus dibayarkan tepat waktu dan tidak boleh ditunda, karena upah merupakan imbalan kepada seseorang yang telah melakukan sesuatu. Sehingga sudah selayaknya Pekerja Rumah Tangga mendapatkan upah tepat pada waktunya.

Yayasan Kencana memberitahukan kepada Pekerja Rumah Tangga mengenai hak dan kewajiban yang semestinya yang terdapat pada Peraturan Menteri Nomor 2 Tahun 2015 tentang Perlindungan Pekerja Rumah Tangga, hak-hak tersebut antara lain : memperoleh informasi mengenai Pengguna, mendapatkan perlakuan yang baik dari Pengguna dan anggota keluarganya, mendapatkan upah sesuai Perjanjian Kerja, mendapatkan makanan dan minuman yang sehat, mendapatkan waktu istirahat yang cukup, mendapatkan hak cuti sesuai dengan kesepakatan, mendapatkan kesempatan melakukan ibadah sesuai dengan agama dan kepercayaan yang dianutnya, mendapatkan tunjangan hari raya, dan berkomunikasi dengan keluarganya.

\section{Simpulan}

Pelaksanaan perlindungan hukum terhadap Pekerja Rumah Tangga belum sepenuhnya sesuai dengan Peraturan Menteri Ketenagakerjaan Nomor 2 Tahun 2015 tentang Perlindungan Pekerja Rumah Tangga. Perlindungan PRT lebih ditentukan oleh baik buruknya perlakuan majikanya,tidak ditentukan oleh Peraturan Perundangundangan yang notabenenya adalah kebijakan pemerintah.

Terdapat hambatan-hambatan dalam pelaksanaan perlindungan hukum terhadap Pekerja Rumah Tangga, hambatan tersebut antara lain: Adanya perlakuan 
kekerasan dalam rumah tangga yang sering di alami oleh Pekerja Rumah Tangga; Adanya pemberian upah yang tidak sesuai dengan yang diperjanjikan dan ; Adanya pengabaian hak-hak Pekerja Rumah Tangga yang lainnya yang meliputi hak untuk mendapatkan makan dan minuman yang sehat, hak untuk mendapatkan cuti sesuai dengan kesepakatan, hak untuk mendapatkan waktu istirahat yang cukup, dan hak untuk berkomunikasi dengan keluarganya.

Upaya-upaya yang dilakukan untuk mengatasi hambatan tersebut antara lain : Adanya sosialisasi tentang Undang-Undang Penghapusan Kekerasan Dalam Rumah Tangga; Adanya penyampaian Perjanjian Kerja yang dilakukan Yayasan Penyalur Pekerja Rumah Tangga; Adanya pemberitahuan mengenai hak dan kewajiban yang semestinya didapatkan Pekerja Rumah Tangga sesuai dengan Peraturan Menteri Nomor 2 Tahun 2015 tentang Perlindungan Pekerja Rumah Tangga.

Untuk melaksanakan perlindungan hukum terhadap Pekerja Rumah Tangga diharapkan adanya sosialisasi yang berkelanjutan tentang segala peraturan dan pelaksanaan mengenai Perlindungan Pekerja Rumah Tangga. Pengawasan terhadap pelaksanaan Peraturan Menteri nomor 2 Tahun 2015 tentang Perlindungan Pekerja Rumah Tangga juga harus dilakukan oleh pihak-pihak yang terkait khususnya dinas tenaga kerja untuk meminimalisir terjadinya penyelewengan Peraturan Menteri Nomor 2 Tahun 2015 tentang Perlindungan Pekerja Rumah Tangga yang dapat merugikan Pekerja Rumah Tangga.

\section{E. Daftar Pustaka}

Adi ,Rianto.Metodologi Penelitian Sosial dan Hukum.Jakarta: Granit.2004

Ali, Zainuddin. Metode Penelitian Hukum .Jakarta:Sinar Grafika.2010

Asyadie ,Zaeni. Hukum Kerja .Jakarta:PR Raja Grafindo Persada.2007

Husni ,Lalau .Pengantar Hukum Tenaga Kerja .Jakarta:PR Raja Grafindo Persada.2003.

Jehani ,Libertus.Hak-hak Pekerja Perempuan.Jakarta:Visi Media.2004

Soekanto ,Soerjono dan Sri Mamudji .Penelitian Hukum Normatif : Suatu Tinjauan Singkat .jakarta:Rajawali Pers.2012

Soekanto,Soerjono.Pengantar Penelitian Hukum.Jakarta:UI Press.1984

Supranto , J.Metode Penelitian Hukum dan Statistik.Jakarta:Rineka Cipta.2003 
Soemitro,Rony Hanintijo.Metodologi Penelitian hukum dan Jurimetri.Jakarta: Ghalia Indonesia.1990

Supranto .Statistik Teori dan Aplikasi.Jakarta:erlangga.2000

Waluyo ,Bambang.Penelitian Hukum Dalam Praktek.Jakarta: Sinar Grafika.2002

Undang-undang Nomor 3 Tahun 2003 Tentang Keenagakerjaan

Undang-undang Nomor 24 Tentang badan Penyelenggara Sosial

Peraturan Mentri Ketenagakerjaan Nomor 2 Tahun 2015 Tentang Perlindunag Pekerja Rumah Tangga 